\title{
Central American Free Trade Agreement-Dominican Republic (CAFTA-DR): What's in It for Florida Agriculture?1
}

Edward Evans ${ }^{2}$

\section{Introduction}

On August 5, 2004, the United States signed the Central American Free Trade Agreement-Dominican Republic (CAFTA-DR) with Costa Rica, Dominican Republic, El Salvador, Guatemala, Honduras, and Nicaragua (http://ita.doc.gov/cafta/index.asp). The Agreement, if approved by all parties, would result in the creation of the second-largest U.S. export market in Latin America, behind only Mexico. It would be the fourteenth-largest U.S. market in the world, with the value of two-way trade (imports plus exports) in 2004 amounting to over US\$33 billion. Arguments for and against the implementation of this Agreement can be found virtually everywhere. Here in Florida the reaction is mixed. The purpose of this article is to summarize the main elements of this Agreement, and to take a closer look at the Agreement to see what is in it for Florida producers.

\section{Main Elements of the Agreement}

The general objective of the Agreement is the eventual removal of all barriers to trade (tariff and non-tariff) on all commodities, save a few which are considered sensitive. The Agreement is modeled after the North American Free Trade Agreement (NAFTA) in that it considers not only trade-specific issues such as tariff reduction, but also liberalization in other areas such as intellectual property, investment, and services. Like NAFTA, the Agreement is comprised of a set of mini agreements between the United States and each of the partners (i.e., each of the six CAFTA-DR countries negotiated separate schedules of commitments providing access for U.S. products). In return, the United States has agreed to provide the same tariff treatment to all the partner countries while making country-specific commitments on tariff-rate quotas (TRQ).

In the case of Agriculture, the key elements of the Agreement fall under four categories: Market Access; Safeguards; Sanitary and Phytosanitary Measures; and Export Subsidies (FAS Online).

\section{Market Access}

Market access is the ease with which one country can sell its products and services in another country. Under this sub-heading, liberalization (opening up a

1. This is EDIS document FE564, a publication of the Department of Food and Resource Economics, Florida Cooperative Extension Service, Institute of Food and Agricultural Sciences, University of Florida, Gainesville, FL. Published June 2005. Please visit the EDIS website at http://edis.ifas.ufl.edu.

2. Edward A. Evans, Assistant Professor, Department of Food and Resource Economics, Tropical Research and Education Center, Homestead, FL, Florida Cooperative Extension Service, Institute of Food and Agricultural Sciences, University of Florida, Gainesville, FL.

The Institute of Food and Agricultural Sciences (IFAS) is an Equal Opportunity Institution authorized to provide research, educational information and other services only to individuals and institutions that function with non-discrimination with respect to race, creed, color, religion, age, disability, sex, sexual orientation, marital status, national origin, political opinions or affiliations. U.S. Department of Agriculture, Cooperative Extension Service, University of Florida, IFAS, Florida A. \& M. University Cooperative Extension Program, and Boards of County Commissioners Cooperating. Larry Arrington, Dean 
market) may occur through a combination of tariff reductions and TRQ expansion (a two-stage tariff that imposes a lower rate of duty on imports up to the quota level and a higher rate of duty on imports over-quota). In general, tariffs will be eliminated on all products (exceptions: sugar in the United States, fresh potatoes and fresh onions entering Costa Rica, and white corn for all CAFTA countries except Costa Rica) over a phase-out period, with some taking effect immediately and others scheduled for phase-out after $5,10,12,15,17$, or 20 years. For most of the commodities, the reductions will occur in equal installments over the course of the agreed upon phase-out period. For others, TRQs will be established or, in some cases, expanded with zero duty for specified import quantities or greater quantities above the quota.

\section{Safeguards}

Safeguards are precautionary measures that permit countries to restrict imports if they cause injury, with the proviso that such restrictions must be for a limited time and nondiscriminatory. For some commodities, the Agreement establishes safeguard mechanisms that would be trigged once commodity imports reach a specified level within a given year. Triggering the safeguard mechanism implies that the country can increase the tariff level for a limited period of time. Safeguard mechanisms end when the phase-out period for a commodity ends. For example, if a commodity has a five-year phase-out period, the safeguarding mechanism would NOT be applicable in the sixth year unless the partners agree to extend it beyond the five-year period.

\section{Sanitary and Phytosanitary (SPS) Measures}

A country can adopt SPS measures, which are designed to protect animal, plant, and human health. All seven members agreed to utilize the science-based framework set out by the World Trade Organization (EDIS publication FE492, Understanding the WTO Sanitary and Phytosanitary Agreement, http://edis.ifas.ufl.edu/FE492). They also agreed to set up a special committee to resolve technical disputes that might arise.

\section{Export Subsidies}

Export subsidies include any form of government payment that helps an exporter or manufacturer to lower their export costs. All parties to the Agreement agreed that they would not use such measures in another member's market unless it was necessary to compete against export subsidies used by a non-member.

\section{Selected Demographics for CAFTA-DR Countries}

Selected demographics for the CAFTA-DR countries are shown in Table 1 . Broadly speaking, the CAFTA-DR countries can be subdivided into two groups: (1) those with relatively high income per person, low poverty, and high literacy; and (2) those with relatively low income per person, high poverty, and low literacy. Countries in the first group are Costa Rica, the Dominican Republic, and El Salvador. Those in the second group are Guatemala, Honduras, and Nicaragua. The data in Table 1 indicate that Guatemala is the most populous, with a population of about 13.9 million, followed by the Dominican Republic (8.7 million), Honduras (6.7 million), and El Salvador (6.5 million). Costa Rica, with the smallest population (3.9 million), has the highest income per person at US\$8,300. This is followed by the Dominican Republic and El Salvador, with per person income of US\$6,300 and US $\$ 4,600$, respectively. For the counties in the second group, the relatively low income levels per person suggest the potential for increased demand for higher-valued commodities (e.g., meat, fruits, and vegetables) as income levels rise. Guatemala has the highest poverty level at $75 \%$, followed by Honduras (53\%) and Nicaragua (50\%). These three countries also have the lowest level of literacy. Of interest is the fact that agriculture is the largest single employer for most of the CAFT-DR countries, with agriculture representing $50 \%$ of total employment. This implies tremendous opportunities to improve agricultural productivity through modern technologies.

\section{Benefits for Florida Producers}

The 2002 Census of Agriculture shows Florida leading cash receipts by commodity/group as 
documented in the 2002 Census for Agriculture (Table 2). The 2002 Census also indicates total receipts of US\$6.33 billion for the top 24 commodities/groups listed. The main agricultural commodities in Florida are greenhouses/nurseries (25.76\%), oranges $(18.46 \%)$, sugarcane $(8.18 \%)$, tomatoes $(8.03 \%)$, dairy products $(5.63 \%)$, and cattle/calves (5.27\%). These six commodities accounted for $71.33 \%$ of the gross receipts (Table 2). The top 13 commodities in Florida accounted for as much as $90.62 \%$ of the total receipts.

In value terms, Florida is the nation's leading producer of oranges, sugarcane, peppers, grapefruit, snap beans, sweet corn, tangerines, cucumbers, and squash (Table 2). Florida ranks second nationally for greenhouses/nurseries, tomatoes, strawberries, watermelons, and avocados.

Assuming that the five categories in Table 3 (Florida's leading agricultural exports) reflect the commodity groupings in which Florida producers may have a comparative advantage, the following analysis examines possible export opportunities that could result from the United States signing the CAFTA-DR Agreement. The five-year average (1999-2003) net import values are illustrated in Table 4. A positive value in the net import column indicates that a CAFTA-DR country is a net importer of U.S. commodities, and a negative value indicates the opposite.

Overall, with respect to these five categories, the CAFTA-DR region is a net exporter to the United States, with a trade surplus of US\$764 million (Table 4). However, while Costa Rica, Guatemala, Honduras, and Nicaragua are net exporters to the United States for the five selected categories, the Dominican Republic and El Salvador are net importers. Over the five-year period, Costa Rica had the biggest trade surplus with the United States, at approximately US $\$ 452.68$ million, while the Dominican Republic was the biggest net importer of U.S. commodities, with a trade deficit of about US\$67.20 million. In terms of individual countries and categories, Table 4 indicates that Costa Rica is a net importer of live animals, and oil seed, grain, and seed from the United States. The Dominican Republic is a net importer of live animals; meat and edible meat offals; and oil seed, grain, and seed. El Salvador is a net importer of live animals, meat, and fruits. Guatemala is a net importer of live animals, and meat. Honduras is a net importer of live animals; meat; and oil seed, grain, and seed. Nicaragua is a net importer of live animals, and oil seed, grain, and seed.

The average five-year values of import commodities from the world (includes all countries) and the total and percentage shares of import commodities from the United States for the CAFTA-DR countries are shown in Table 5. Defining an export opportunity (from the US/Florida perspective) to mean a situation in which these countries currently buy less than $50 \%$ of their import requirements of the selected commodities from the United States, the following observations are made in relation to the information presented in Table 5:

1. El Salvador, Nicaragua and Honduras represent the best export opportunities. Of the three, El Salvador, which has the third highest GDP per person and a population of over six million, imports only $11.85 \%$ of these commodities from the United States and thus presents a particularly good export opportunity.

2. Dominican Republic represents the worst export opportunity since it imports over $80 \%$ of the selected commodities from the United States.

3. El Salvador shows good potential opportunities in all five categories.

4. In the other CAFTA-DR counties, potential opportunities exist in the following categories:

- Costa Rica: meat (30.54\%), vegetables $(12.79 \%)$, and fruits $(41.91 \%)$.

- Guatemala: live animals (48.02\%) and vegetables $(32.67 \%)$.

- Honduras: live animals (9.54\%), vegetables $(30.03 \%)$, and fruits $(39.44 \%)$.

- Nicaragua: live animals (11.18\%), vegetables (16.34\%), and fruits $(28.46 \%)$. 
The current and proposed level of market access for selected commodities within the five groupings if the trade agreement were to be implemented are shown in Table 6 . The information in Table 6 supports the view that the current low level of imports of these commodities from the United States could be the result of the existing limited market access.

\section{Concluding Remarks}

There is no doubt that implementing the CAFTA-DR Agreement will lead to an expansion of trade between the United States and the CAFTA-DR countries. As it stands, there appear to be advantages for U.S. producers from the Agreement, given the already low duties on agricultural imports from these countries to the United States and the relatively high duties placed on U.S. agricultural exports. However, as with any trade agreement, there will be "winners" and "losers". In the absence of a crystal ball, there are potential benefits for U.S. and Florida producers from the Agreement. The conclusions reached are made based on two premises. The first premise is the observation that Florida producers still maintain a trade surplus for some of the selected commodities, notwithstanding the relatively high tariff faced by U.S. producers/exporters. The second premise is that removing trade restrictions should enable more Florida producers to penetrate more CAFTA-DR markets. It should be noted that trade flows and patterns can and do change over time and that countries currently importing a particular commodity can, with the requisite level of investment and technological support, become net exporters in the near future.

\section{References}

Evans, Edward. 2005. Understanding the WTO Sanitary and Phytosanitary Agreement. Electronic Data Information Source (EDIS) FE492, Department of Food and Resource Economics, University of Florida, Gainesville, FL. http://edis.ifas.ufl.edu/FE492.

FAS Online. 2005. Foreign Agricultural Service, United States Department of Agriculture, Washington, D.C. http://www.fas.usda.gov.
Florida Agriculture Statistical Directory. 2004. Florida Department of Agriculture and Consumer Services, Tallahassee, FL. http://www.florida-agriculture.com.

Posson, Parr. 2004. Central America Free Trade: What's at Stake for Texas Agriculture. Center for North American Studies (CNAS), Texas A\&M University, College Station, TX. http://cnas.tamu.edu/publications/PowerPoint/ CAFTATVA04.ppt.

United Nations. 2004. U.N. Commodity Trade Statistical Database. United Nations, New York, NY. http://unstats.un.org/unsd/comtrade. 
Table 1. Selected CAFTA-DR demographics.

\begin{tabular}{|lcccccc|}
\hline \hline \multicolumn{1}{c}{ Country } & Population & GDP Per Person & Poverty & Literacy & Ag Population \\
\cline { 1 - 3 } & (millions) & (US dollars $)$ & $(\%)$ & $(\%)$ & $(\%)$ \\
Costa Rica & 3.9 & 8,300 & 21.0 & 96.0 & 20.0 \\
El Salvador & 6.5 & 4,600 & 48.0 & 80.0 & 30.0 \\
Guatemala & 13.9 & 3,900 & 75.0 & 71.0 & 50.0 \\
Honduras & 6.7 & 2,500 & 53.0 & 76.0 & 34.0 \\
Nicaragua & 5.1 & 2,200 & 50.0 & 68.0 & 42.0 \\
Dominican Republic & 8.7 & 6,300 & 25.0 & 84.0 & 17.0 \\
Total/Average & 44.8 & 4,633 & 45.3 & 79.2 & 32.2 \\
\hline Source: Adapted from Parr Rosson's 2004 presentation & & & \\
\hline \hline
\end{tabular}

Table 2. Florida's leading cash recipts by commodity, 2002.

\begin{tabular}{|lcccc|}
\hline \hline \multicolumn{1}{c}{ Commodity } & $\begin{array}{c}\text { Florida } \\
\text { Receipts }\end{array}$ & $\begin{array}{c}\text { Share of } \\
\text { Receipts }\end{array}$ & $\begin{array}{c}\text { Cumulative } \\
\text { Share }\end{array}$ & $\begin{array}{c}\text { National } \\
\text { Ranking }\end{array}$ \\
\hline & $\left(\begin{array}{l}\text { thousand } \\
\text { Greenhouse/Nursery }\end{array}\right.$ & $(\%)$ & $(\%)$ & $($ number $)$ \\
Oranges & $1,629,993$ & 25.76 & 25.76 & 2 \\
Sungarcane & $1,168,211$ & 18.46 & 44.22 & 1 \\
Tomatoes (fresh \& processed) & 517,925 & 8.18 & 52.40 & 1 \\
Dairy Products & 508,320 & 8.03 & 60.43 & 2 \\
Cattle/Calves & 356,184 & 5.63 & 66.06 & 14 \\
Peppers & 333,413 & 5.27 & 71.33 & 26 \\
Potatoes & 218,960 & 3.46 & 74.79 & 1 \\
Chicken Broilers & 211,622 & 3.34 & 78.13 & 4 \\
Grapefruit & 195,579 & 3.09 & 81.22 & 15 \\
Strawberries & 183,680 & 2.9 & 84.12 & 1 \\
Snap Beans (fresh) & 153,472 & 2.43 & 86.55 & 2 \\
Eggs & 148,764 & 2.35 & 88.90 & 1 \\
Sweet Corn & 109,012 & 1.72 & 90.62 & 12 \\
Tangerines & 101,538 & 1.60 & 92.22 & 1 \\
Cucumbers & 98,047 & 1.55 & 93.77 & 1 \\
Aquaculture & 91,942 & 1.45 & 95.22 & 1 \\
Watermelons & 77,000 & 1.22 & 96.44 & - \\
Squash & 62,238 & 0.98 & 97.42 & 2 \\
Peanuts & 40,611 & 0.64 & 98.06 & 1 \\
Cabbage (fresh) & 35,011 & 0.55 & 98.61 & 7 \\
Cotton & 28,928 & 0.46 & 99.07 & 5 \\
Tobacco & 22,815 & 0.36 & 99.43 & 16 \\
Avocados & 18,244 & 0.29 & 99.72 & \\
Total & 17,195 & 0.27 & 99.99 & 100 \\
\hline Source: Compiled by author from information obtained from Florida Statistical & Directory, 2004 & \\
\hline \hline
\end{tabular}


Table 3. Florida's top five agricultural exports.

\begin{tabular}{|lcc|}
\hline \hline \multicolumn{1}{c}{ Category } & Value & Share \\
\hline Fruits and Preparations & $(\$$ million $)$ & $(\%)$ \\
Vegetables and Preparations & 569 & 43.77 \\
Live Animals and Meat & 138 & 10.61 \\
Oil seed, grain, seed & 53 & 4.08 \\
Poultry and Products & 37 & 2.85 \\
Total & 28 & 2.15 \\
\hline Source: FAS Online & 825 & 63.46 \\
\hline \hline
\end{tabular}

Table 4. Average value of CAFTA-DR net imports from United States.

\begin{tabular}{|c|c|c|c|}
\hline & \multicolumn{3}{|c|}{ Average 1999-2003 } \\
\hline & Imports from US & Exports to US & Net Imports \\
\hline & \multicolumn{3}{|c|}{ (US dollars) } \\
\hline \multicolumn{4}{|l|}{ COSTA RICA } \\
\hline Live Animals & $2,183,899$ & 439,202 & $1,744,697$ \\
\hline Meat and Edible Meat Offals & $2,731,830$ & $24,895,319$ & $-22,163,489$ \\
\hline Vegetables & $2,888,230$ & $50,810,486$ & $-47,922,257$ \\
\hline Fruits & $9,547,281$ & $438,896,570$ & $-429,348,289$ \\
\hline Oil sseed, grain, seed & $51,892,351$ & $6,882,174$ & $45,010,177$ \\
\hline Total & $69,243,591$ & $521,923,751$ & $-452,680,160$ \\
\hline \multicolumn{4}{|l|}{ DOMINICAN REPUBLIC } \\
\hline Live Animals & $3,048,000$ & 224,000 & $2,824,000$ \\
\hline Meant and Edible Meat Offals & $11,548,000$ & 0 & $11,548,000$ \\
\hline Vegetables & $12,834,000$ & $19,451,000$ & $-6,617,000$ \\
\hline Fruits & $12,880,000$ & $23,684,000$ & $-10,804,000$ \\
\hline Oil seed, grain, seed & $70,804,000$ & 551,000 & $70,253,000$ \\
\hline Total & $111,114,000$ & $43,910,000$ & $67,204,000$ \\
\hline \multicolumn{4}{|l|}{ EL SALVADOR } \\
\hline Live Animals & $2,035,454$ & 442,881 & $1,592,573$ \\
\hline Meat and Edible Meat Offals & $2,593,236$ & 12,270 & $2,580,967$ \\
\hline Vegetables & $1,783,147$ & $6,059,242$ & $-4,276,095$ \\
\hline Fruits & $8,511,010$ & $2,606,154$ & $5,904,855$ \\
\hline Oil seed, grain, seed & $1,519,281$ & $1,845,720$ & $-326,439$ \\
\hline Total & $16,442,127$ & $10,966,266$ & $5,475,861$ \\
\hline
\end{tabular}


Table 4. Average value of CAFTA-DR net imports from United States.

\begin{tabular}{|c|c|c|c|}
\hline & \multicolumn{3}{|c|}{ Average 1999-2003 } \\
\hline & Imports from US & Exports to US & Net Imports \\
\hline & \multicolumn{3}{|c|}{ (US dollars) } \\
\hline \multicolumn{4}{|l|}{ GUATEMALA } \\
\hline Live Animals & $2,522,201$ & 45,418 & $2,476,783$ \\
\hline Meat and Edible Meat Offals & $20,448,344$ & 2,118 & $20,446,225$ \\
\hline Vegetables & $4,115,981$ & $27,296,123$ & $-23,180,142$ \\
\hline Fruits & $11,156,345$ & $208,722,499$ & $-197,566,154$ \\
\hline Oil seed, grain, seed & $11,648,674$ & $14,148,955$ & $-2,500,281$ \\
\hline Total & $49,891,545$ & $250,215,113$ & $-200,323,569$ \\
\hline \multicolumn{4}{|l|}{ HONDURAS } \\
\hline Live Animals & 724,508 & 126,226 & 598,282 \\
\hline Meat and Edible Meat Offals & $8,047,375$ & 412,507 & $7,634,868$ \\
\hline Vegetables & $4,629,875$ & $31,865,546$ & $-27,235,671$ \\
\hline Fruits & $6,751,668$ & $137,348,378$ & $-130,596,710$ \\
\hline Oil seed, grain, seed & $2,561,919$ & 247,567 & $2,314,352$ \\
\hline Total & $22,715,344$ & $170,000,224$ & $-147,284,880$ \\
\hline \multicolumn{4}{|l|}{ NICARAGUA } \\
\hline Live Animals & 850,587 & 362,777 & 487,809 \\
\hline Meat and Edible Meat Offals & $2,043,235$ & $28,403,042$ & $-26,359,807$ \\
\hline Vegetables & $2,471,000$ & $3,349,263$ & $-878,263$ \\
\hline Fruits & $1,138,070$ & $12,001,715$ & $-10,863,645$ \\
\hline Oil seed, grain, seed & $2,073,586$ & 825,544 & $1,248,042$ \\
\hline Total & $8,576,477$ & $44,942,340$ & $-36,365,863$ \\
\hline
\end{tabular}

Table 5. CAFTA-DR countries' share of imports from United States.

\begin{tabular}{|c|c|c|c|}
\hline & \multicolumn{3}{|c|}{ Average 1999-2003 } \\
\hline & Imports from US & Imports from World & US Share \\
\hline & \multicolumn{2}{|c|}{ (US dollars) } & (\%) \\
\hline \multicolumn{4}{|l|}{ COSTA RICA } \\
\hline Live Animals & $2,183,899$ & $3,527,184$ & 61.92 \\
\hline Meat and Edible Meat Offals & $2,731,830$ & $8,944,866$ & 30.54 \\
\hline Vegetables & $2,888,230$ & $22,573,864$ & 12.79 \\
\hline Fruits & $9,547,281$ & $22,782,549$ & 41.91 \\
\hline Oil sseed, grain, seed & $51,892,351$ & $61,797,338$ & 83.97 \\
\hline
\end{tabular}


Table 5. CAFTA-DR countries' share of imports from United States.

\begin{tabular}{|c|c|c|c|}
\hline \multirow[b]{4}{*}{ Total } & \multicolumn{3}{|c|}{ Average 1999-2003 } \\
\hline & Imports from US & Imports from World & US Share \\
\hline & \multicolumn{2}{|c|}{ (US dollars) } & $(\%)$ \\
\hline & $69,243,591$ & $119,625,801$ & 57.88 \\
\hline \multicolumn{4}{|l|}{ DOMINICAN REPUBLIC } \\
\hline Live Animals & $3,048,000$ & $3,141,000$ & 97.04 \\
\hline Meant and Edible Meat Offals & $11,548,000$ & $12,203,000$ & 94.63 \\
\hline Vegetables & $12,834,000$ & $25,093,000$ & 51.15 \\
\hline Fruits & $12,880,000$ & $15,283,000$ & 84.28 \\
\hline Oil seed, grain, seed & $70,804,000$ & $76,349,000$ & 92.74 \\
\hline Total & $111,114,000$ & $132,069,000$ & 84.13 \\
\hline \multicolumn{4}{|l|}{ EL SALVADOR } \\
\hline Live Animals & $2,035,454$ & $15,521,985$ & 13.11 \\
\hline Meat and Edible Meat Offals & $2,593,236$ & $34,483,505$ & 7.52 \\
\hline Vegetables & $1,783,147$ & $41,905,635$ & 4.30 \\
\hline Fruits & $8,511,010$ & $41,434,629$ & 20.31 \\
\hline Oil seed, grain, seed & $1,519,281$ & $5,374,004$ & 28.27 \\
\hline Total & $16,442,127$ & $138,719,758$ & 11.85 \\
\hline \multicolumn{4}{|l|}{ GUATEMALA } \\
\hline Live Animals & $2,522,201$ & $5,252,678$ & 48.02 \\
\hline Meat and Edible Meat Offals & $20,448,344$ & $32,046,518$ & 63,81 \\
\hline Vegetables & $4,115,981$ & $12,597,272$ & 32.67 \\
\hline Fruits & $11,156,345$ & $22,234,272$ & 50.18 \\
\hline Oil seed, grain, seed & $11,648,674$ & $17,920,826$ & 65.00 \\
\hline Total & $49,891,545$ & $90,051,567$ & 55.40 \\
\hline \multicolumn{4}{|l|}{ HONDURAS } \\
\hline Live Animals & 724,508 & $7,593,285$ & 9.54 \\
\hline Meat and Edible Meat Offals & $8,047,375$ & $11,904,160$ & 67.60 \\
\hline Vegetables & $4,629,875$ & $15,417,075$ & 30.03 \\
\hline Fruits & $6,751,668$ & $17,120,220$ & 39.44 \\
\hline Oil seed, grain, seed & $2,561,919$ & $4,651,395$ & 55.08 \\
\hline Total & $22,715,344$ & $56,686,135$ & 40.07 \\
\hline \multicolumn{4}{|l|}{ NICARAGUA } \\
\hline Live Animals & 850,587 & $7,610,054$ & 11.18 \\
\hline Meat and Edible Meat Offals & $2,043,235$ & $3,075,243$ & 66.44 \\
\hline Vegetables & $2,471,000$ & $15,125,759$ & 16.34 \\
\hline Fruits & $1,138,070$ & $3,998,669$ & 28.46 \\
\hline Oil seed, grain, seed & $2,073,586$ & $3,349,452$ & 61.91 \\
\hline Total & $8,576,477$ & $33,159,178$ & 25.86 \\
\hline
\end{tabular}


Table 6. Proposed market access under CAFTA-DR for selected commodities of interest to Florida.

\begin{tabular}{|c|c|c|c|}
\hline Category & $\begin{array}{c}\text { Selected } \\
\text { Commodities }\end{array}$ & Current Tariffs & Proposed Market Access \\
\hline \multirow[t]{4}{*}{$\begin{array}{l}\text { Animal } \\
\text { Products }\end{array}$} & Beef & $\begin{array}{l}\text { Applied rates } 15-30 \% \text {, } \\
\text { can reach } 79 \%\end{array}$ & $\begin{array}{l}\text { Immediate tariff elimination on prime and choice } \\
\text { cuts in all except Dominican Republic, which } \\
\text { established a TRQ that increases annually as } \\
\text { duties are eliminated } \\
\text { Duties on other beef products and beef offals } \\
\text { scheduled for phase-out over } 15 \text { years }\end{array}$ \\
\hline & Poultry & $\begin{array}{l}\text { Applied rates up to } \\
164 \% \text {, can reach } \\
250 \%\end{array}$ & $\begin{array}{l}\text { Immediate duty-free access on chicken leg } \\
\text { quarters through TRQs that increase annually; } \\
\text { duties eliminated in } 17-20 \text { years }\end{array}$ \\
\hline & & & $\begin{array}{l}\text { Duties on other poultry products (e.g., wings, } \\
\text { breast meat, and mechanically deboned poultry } \\
\text { meat) scheduled for elimination within } 10 \text { years }\end{array}$ \\
\hline & Dairy Products & $\begin{array}{l}\text { Applied rates up to } \\
60 \% \text {, can reach } 100 \%\end{array}$ & $\begin{array}{l}\text { Immediate duty-free access through TRQs that } \\
\text { increase each year; all duties eliminated within } \\
20 \text { years }\end{array}$ \\
\hline \multirow[t]{2}{*}{$\begin{array}{l}\text { Vegetables and } \\
\text { Preparations }\end{array}$} & Fresh vegetables & $\begin{array}{l}\text { Applied rates } 15-47 \% \text {, } \\
\text { can reach } 60 \%\end{array}$ & $\begin{array}{l}\text { Immediate tariff elimination with exception of } \\
\text { sweet corn, lettuce, cauliflower, and broccoli }\end{array}$ \\
\hline & Frozen vegetables & $\begin{array}{l}\text { Applied rates } 15-47 \% \text {, } \\
\text { can reach } 60 \%\end{array}$ & $\begin{array}{l}\text { Immediate elimination for Nicaragua; phase-out } \\
\text { within } 10-12 \text { years for the other countries }\end{array}$ \\
\hline \multirow[t]{3}{*}{$\begin{array}{l}\text { Fruits and } \\
\text { Preparations }\end{array}$} & Fresh fruits & $\begin{array}{l}\text { Applied rates } 15 \% \text {, can } \\
\text { reach } 150 \%\end{array}$ & $\begin{array}{l}\text { Approximately } 70 \% \text { of U.S. fruits and nuts } \\
\text { receive immediate duty-free access; phase-out } \\
\text { duties on others over 5-10 years }\end{array}$ \\
\hline & $\begin{array}{l}\text { Frozen orange } \\
\text { juice }\end{array}$ & $\begin{array}{l}\text { Applied rates } 20-60 \% \text {, } \\
\text { can reach } 150 \%\end{array}$ & $\begin{array}{l}\text { Immediate elimination of duties in all countries } \\
\text { except Dominican Republic, which will eliminate } \\
\text { duties within } 15 \text { years }\end{array}$ \\
\hline & Grapefruit juice & $\begin{array}{l}\text { Applied rates } 20-60 \% \text {, } \\
\text { can reach } 150 \%\end{array}$ & Immediate elimination of all duties \\
\hline
\end{tabular}

